\title{
Evaluasi Keberhasilan Guru SD dalam Penyampaian Materi Geometri Berdasarkan Model Van Hiele Sesuai K-13 Di Kabupaten Asahan
}

\author{
Mapilindo, Sri Rahmayanti, Wan Nurul Atikah Nasution
}

\section{(C) 2020 JEMS (Jurnal Edukasi Matematika dan Sains)}

This is an open access article under the CC-BY-SA license (https://creativecommons.org/licenses/bysa/4.0/) ISSN 2337-9049 (print), ISSN 2502-4671 (online)

\begin{abstract}
Abstrak:
Geometri menempati posisi khusus dalam kurikulum matematika sekolah, karena banyaknya konsep yang termuat di dalamnya dan aplikasinya dalam kehidupan sehari-hari. Pada dasarnya geometri mempunyai peluang yang lebih besar untuk dipahami siswa dibandingkan dengan cabang matematika yang lain, namun bukti- bukti di lapangan menunjukkan bahwa hasil belajar geometri masih rendah. Maka itu penelitian ini bertujuan untuk mengevaluasi hasil pembelajaran matematika materi geometri menggunakan teori Van Hile yang diterapkan guru sesaui kurikulum 2013. Metode penelitian yaitu deskriptif dengan cara pengambilan sampel dilakukan dengan menggunakan metode pengambilan sampel secara purposive (purposive sampling) yang bersumber dari populasi penelitian. Pengambilan sampel berdasarkanpada daerah tempat guru mengajar. Hasil penelitian menunjukkan bahwa dengan penerapam tahap pembelajaran Van Hiele dapat membantu siswa SD dalam memahami konsep dasar geometri sesuai kurikulum 2013.
\end{abstract}

Kata Kunci: Evaluasi, Keberhasilan Guru; SD; Geometri, Model Van Hiele; K-13.

\section{Pendahuluan}

Matematika diajarkan sebagai salah satu mata pelajaran di setiap jenjang pendidikan. Dan tuntutan perkembangan yang nyata dari lingkungan hidup senantiasa berkembang seiring dengan kemajuan ilmu dan teknologi. Tujuan diajarkannya matematika di setiap jenjang pendidikan yaitu (1) Tujuan yang bersifat formal yang menekankan kepada penalaran anak

Mapilindo, Universitas Asahan

Unapindo63@gmail.com

Sri Rahmayanti, Universitas Asahan

yantinasution@gmail.com

Wan Nurul Atikahi, Universitas Asahan wannurulatikahnasution@gmail.com

\begin{abstract}
:
Geometry occupies a special position in the school mathematics curriculum, because of the many concepts contained in it and its applications in everyday life. Basically, geometry has a greater chance of being understood by students compared to other branches of mathematics, but evidence in the field shows that learning outcomes of geometry are still low. Therefore, this study aims to evaluate the results of learning mathematics geometry material using the Van Hile theory applied by the teacher according to the 2013 curriculum. The research method is descriptive by means of sampling carried out using purposive sampling method (purposive sampling) sourced from the study population. Sampling is based on the area where the teacher teaches. The results showed that applying the Van Hiele learning stage could help elementary students understand the basic concepts of geometry according to the 2013 curriculum.
\end{abstract}

Keywords: Evaluation; Teacher Succes;, Elementary School; Geometry; Van Hiele Model; K-13. 
dan pembentukan sikap anak; dan (2) Tujuan yang bersifat material yang menekankan kepada keterampilan hitung, menyelesaikan soal dan penerapan matematika.

Belajar matematika, siswa diharapkan dapat mengembangkan kemampuan berpikir logis, sistematis dan kritis Materi geometri menempati posisi khusus dalam kurikulum matematika karena banyaknya konsep yang termuat di dalamnya. Dari sudut pandang psikologi, geometri merupakan penyajian abstraksi pengalaman visual dan special misalnya bidang, pola, pengukuran, dan pemetaan. Geometri menjadi esensi bagi setiap pokok bahasan matematika sekolah pada setiap jenjang pendidikan. Tujuan pengajaran di jenjang pendidikan pada dasarnya mengacu pada penataan nalar dan pembentukan sikap, juga ada penerapan geometri dan keterampilan geometri. Dengan kata lain, tujuan pembelajaran geometri adalah menumbuh kembangkan lima keterampilan dasar siswa yaitu keterampilan visual (visual skill), keterampilan verbal (verbal skill), keterampilan menggambar (drawing skill), keterampilan logika (logical skill dan keterampilan terapan (applied skill). Pembelajaran geometri khususnya yang berkaitan dengan pokok bahasan luas bangun datar sering sulit dipahami oleh siswa. Materi ini cukup sukar serta memerlukan pemahaman yang cukup tinggi, sehingga dalam mengerjakan materi geometri di SD, seorang guru harus dapat menyajikan materi awal secara konkrit, dan menghubungkan pembelajaran geometri dengan benda- benda yang nyata sehingga siswa dapat memahami materi dengan mudah. Suasana kelas yang diciptakan guru dan bagaimana guru menyampaikan materi ajarnya kepada siswa akan menentukan keberhasilan pembelajaran. Iklim belajar mengajar yang tepat dan pengolaan kelas yang baik, memungkinkan siswa merasa aman untuk belajar. Dengan demikian guru harus dapat memilih dan menggunakan model, dan metode pembelajaran yang dipilih seharusnya dapat membantu siswa dalam memahami materi yang diajarkan. Kesulitan-kesulitan tersebut, timbul karena guru tidak memberikan kesempatan kepada siswa untuk bertanya atau terlibat secara langsung dalam pembelajaran. Kesulitan yang dialami siswa lebih diperjelas oleh prestasi belajar belajar matematika yang rendah terutama dalam materi geometri. Untuk melihat bagaimana kemampuan intelektual siswa dalam belajar geometri, perlu ditelusuri tahap berikutnya. Penerapan Van Hiele diyakini dapat mengatasi kesulitan belajar siswa dalam geometri. Teori Van Hiele lebih menekankan pada pembelajaran yang disesuaikan dengan tahap berpikir siswa. Hal ini yang mendorong penulis untuk melakukan penelitian untuk menganalisis hasil evaluasi tahap penyampaian guru dalam proses pembelajaran geometri menurut teori Van Hiele berdasarkan kurikulum 2013.

\section{Metode}

Penelitian ini akan dilakukan di Fakultas Keguruan Dan Ilmu Pendidikan Universitas Asahan. Populasi penelitian adalah Mahsiswa Program Studi Pendidikan Matematika Universitas Asahan yang mengajar di SD di Kabupaten Asahan. Mengingat populasi penelitian sangat banyak, maka perlu dilakukan pengambilan sampel guna mengatasi keterbatasan sumberdaya yang digunakan dalam penelitian ini. Pengambilan sampel dilakukan dengan menggunakan metode pengambilan sampel secara purposive (purposive sampling) yang bersumber dari populasi penelitian. Pengambilan sampel berdasarkan pada daerah tempat guru mengajar yaitu mengajar. Kriteria yang diambil yaitu daerah tempat guru mengajar yaitu mengajar di daerah kota, di daerah pinggiran kota, dan didaerah pedesaan. Penelitian ini adalah penelitian deskriptif karena penulis ingin memperoleh informasi dan gambaran tentang kemampuan guru dalam penyampaian materi geometri khususnya bangun datar yang berpandu pada model Van Hiele. Data yang digunakan dalam penelitian ini dikumpulkan dengan 
menggunakan teknik tes esai, yaitu: suatu daftar yang berisikan rangkaian pertanyaan mengenai suatu masalah pokok bahasan dalam pembelajaran geometri.

Jawaban responden akan dianalisisi dengan menggunakan fase yang diterapkan untuk mengetahui seberapa jauh guru telah menerapkan teori Van Hiele dalam proses pembelajaran geometri. Rambu-rambu untuk memperoleh kemampuan guru dalam menerapkan teori Van Hiele seperti tampak pada Tabel 3.5

Tabel 1. Rambu - rambu Teknik Penilaian.

\begin{tabular}{|c|c|}
\hline Fase & Kegiatan dalam Pembelajaran \\
\hline \multirow[t]{2}{*}{ Informasi } & $\begin{array}{l}\text { 1. Tanya jawab untuk mengetahui pengetahuan } \\
\text { awal yang diketahui oleh siswa pada pokok } \\
\text { bahasan bangun datar. }\end{array}$ \\
\hline & $\begin{array}{l}\text { 2. Mempelajari petunjuk yang muncul dalam } \\
\text { rangka untuk menentukan pembelajaran } \\
\text { selanjutnya. }\end{array}$ \\
\hline \multirow[t]{2}{*}{ Orientasi Langsung } & $\begin{array}{l}\text { Guru/ siswa menyediakan alat-alat peraga untuk } \\
\text { mengetahui bentuk dan cirri-ciri bangun datar. }\end{array}$ \\
\hline & $\begin{array}{l}\text { 2. Guru memfasilitasi siswa untuk menggali topic } \\
\text { yang dipelajari melalui alat peraga. }\end{array}$ \\
\hline \multirow[t]{4}{*}{ Penjelasan } & $\begin{array}{l}\text { Menjelaskan kepada siswa definisi dari bangun } \\
\text { datar dan memberikan penjelasan tentang rumus } \\
\text { bangun datar. }\end{array}$ \\
\hline & $\begin{array}{l}\text { 2. Menjelaskan tentang bentuk dan sifat-sifat } \\
\text { bangun datar berdasarkan petunjuk-petunjuk } \\
\text { dari alat peraga. }\end{array}$ \\
\hline & $\begin{array}{l}\text { 3. Membantu siswa untuk menggunakan ide-ide } \\
\text { mengenai struktur yang diobservasi. }\end{array}$ \\
\hline & $\begin{array}{l}\text { Membantu siswa untuk menggunakan bahasa } \\
\text { yang tepat dan akurat untuk menjelaskan hasil } \\
\text { yang diperoleh. }\end{array}$ \\
\hline \multirow[t]{2}{*}{ Orientasi Bebas } & $\begin{array}{l}\text { 1. Memberikan kepada siswa tugas-tugas kompleks } \\
\text { yang memerlukan banyak langkah dan banyak } \\
\text { cara, serta open ended berdasarkan penjelasan } \\
\text { dari guru dan pengamatan yang dipelajari. }\end{array}$ \\
\hline & $\begin{array}{l}\text { 2. Menjelaskan kepada siswa hubungan antara } \\
\text { objek-objek pada bangun datar. }\end{array}$ \\
\hline \multirow[t]{2}{*}{ Integrasi } & $\begin{array}{l}\text { 1. Guru menyuruh siswa untuk meninjau kembali } \\
\text { dan menyuruh siswa untuk meringkas apa yang } \\
\text { telah dipelajari. }\end{array}$ \\
\hline & $\begin{array}{l}\text { 2. Guru membantu siswa untuk membuat } \\
\text { kesimpulan materi pelajaran. }\end{array}$ \\
\hline
\end{tabular}

Analisis data yang dilakukan untuk menentukan tahap penyampaian guru berdasarkan fase, apabila subyek melakukan tahap penyampaian berdasarkan indikator-indikator pada setiap fase dan memenuhi kriteria sesuai dengan model Van Hiele. Subyek melakukan penyampaian dikelas berdasarkan model Van Hiele apabila telah melakukan indikator-indikator pada fase dengan ketentuan sebagai berikut: melakukan fase informasi apabila telah melaksanakan 2 (dua) indicator sekaligus,m elakukan fase orientasi langsung apabila telah melaksanakan 2 (dua) 
indicator sekaligus, bukan hanya menyediakan alat peraga, melakukan fase penjelasan apabila telah melakukan minimal 2 (dua) indicator yang dilaksanakan, melakukan fase orientasi bebas apabila telah melaksanakan 2 (dua) indicator dilaksanakan, bukan hanya memberikan tugas atau latihan-latihan kepada siswa, dan melakukan fase integrasi apabila telah melaksanakan 2 (dua) indicator, bukan hanya menyuruh siswa memberikan kesimpulan berdasarkan penjelasan guru.

Analisa dari subyek dikatakan melaksanakan pembelajaran dengan model Van Hiele sesuai dengan table dibawah ini.

\begin{tabular}{|c|c|c|}
\hline No & Prosentase Indikator Yang Nampak & Kriteria \\
\hline 1. & $90 \%-100 \%$ & Sangat baik \\
\hline 2. & $80 \%-89 \%$ & Baik \\
\hline 3. & $70 \%-79 \%$ & Cukup baik \\
\hline 4. & $60 \%-69 \%$ & Sedang \\
\hline 5. & $50 \%-59 \%$ & Kurang \\
\hline 6. & $<50 \%$ & Kurang baik \\
\hline
\end{tabular}

\section{Hasil dan Pembahasan}

Dari hasil analisis data yang telah dikemukakan secara umum dapat dilihat bahwa subyek penelitian dalam penyampaian materi ajar menggunakan metode ekspositori/ceramah yaitu 30 (tiga puluh) orang, menggunakan metode Tanya jawab yaitu 6 (enam) orang, metode latihan yaitu 10 (sepuluh) orang,metode diskusi 2 (dua) orang dan metode penemuan terbimbing yaitu 1 (satu) orang. Berdasarkan table 4.1 dapat diuraikan kesimpulan sebagai berikut sebanyak 70\% guru yang mengerjakan indikator 1 dan $2 \%$ guru yang mengerjakan indikator 2 pada fase informasi, sebanyak $73 \%$ guru yang mengerjakan indikator 2 dan 33\% yang mengerjakan indikator 2 pada fase orientasi langsung, sebanyak $100 \%$ guru yang mengerjakan indikator 1 dan 2,3\% indikator 3 dan $0 \%$ indikator 4 pada fase penjelasan, sebanyak $0 \%$ guru yang mengerjakan indikator 1 dan $57 \%$ indikator 2 pada fase orientasi bebas, sebanyak $27 \%$ guru yang mengerjakan indikator 1 dan $47 \%$ indikator 2 pada fase integrasi.

Berdasarkan uraian diatas dapat dilihat guru melaksanakan kegiatan pembelajaran langsung pada fase penjelasan. Guru langsung memberikan penjelasan kepada siswa tentang bangun datar. Proses Tanya jawab hanya dilaksanakan pada awal pelajaran. Guru tidak melibatkan siswa untuk mengeluarkan ide-ide yang muncul dari petunjuk-petunjuk dari alat peraga.

Guru tidak memberikan tugas kepada siswa yang memerlukan banyak langkah dan banyak cara serta open ended. Pemberian tugas hanya sebatas latihan dengan soal-soal sederhana, contohnya mencari luas bangun datar. Sehingga siswa tidak diberi kesempatan untuk bereksplorasi dengan lat peraga.penjelasan tersebut sangat berpengaruh bagi siswa untuk menggali lagi hal-hal yang berkaitan dengan bangun datar, apabila guru mencari ide lain dalam penjelasan.

Kesimpulan lain yang dapat dihasilkan dari table 4.1 yaiti ; 8 (delapan) orang yang melalui fase informasi, 6 (enam) orang yang melalui fase orientasi langsung, 30 (tiga puluh) orang yang melalui fase penjelasan, 12 (dua belas) orang yang melalui fase orientasi bebas dan 3 (tiga) orang yang, elalui fase integrasi. Beberapa subyek melaksanakan fase yang dilalui tidak berurutan antara fase awal ke fase berikutnya. Berdasarkan table 4.1, criteria proses penyampaian materi berdasarkan indikator dan fase setiap guru dilihat pada table 4.2. 
Tabel 3. Proses Penyampaian Materi Berdasarkan Indikator dan Fase

\begin{tabular}{|c|c|c|c|c|c|}
\hline No & $\begin{array}{c}\text { Kode } \\
\text { Subyek }\end{array}$ & $\begin{array}{c}\text { Jumlah Indikator } \\
\text { yang tampak }\end{array}$ & $\begin{array}{c}\text { Fase yang } \\
\text { dilalui }\end{array}$ & $\begin{array}{c}\text { Prosentase } \\
(\%)\end{array}$ & Kriteri \\
\hline 1 & K.1 & 6 & II, III & $50 \%$ & Kurang \\
\hline 2 & K.2 & 5 & III & $42 \%$ & Kurang \\
\hline 3 & K.3 & 6 & III, IV & $50 \%$ & Kurang \\
\hline 4 & K.4 & 7 & I, II, III, V & $58 \%$ & Kurang \\
\hline 5 & K.5 & 6 & I, III, V & $50 \%$ & Kurang \\
\hline 6 & K.6 & 4 & III & $33 \%$ & Kurang \\
\hline 7 & K.7 & 6 & I, III & $50 \%$ & Kurang \\
\hline 8 & K.8 & 4 & III & $33 \%$ & Kurang \\
\hline 9 & K.9 & 4 & II, III & $33 \%$ & Kurang \\
\hline 10 & K.10 & 5 & I, III & $42 \%$ & Kurang \\
\hline 11 & P.1 & 5 & III & $42 \%$ & Kurang \\
\hline 12 & P.2 & 6 & III & $50 \%$ & Kurang \\
\hline 13 & P.3 & 6 & III & $50 \%$ & Kurang \\
\hline 14 & P. 4 & 6 & III & $50 \%$ & Kurang \\
\hline 15 & P.5 & 5 & II, III & $42 \%$ & Kurang \\
\hline 16 & P.6 & 4 & III & $33 \%$ & Kurang \\
\hline 17 & P.7 & 4 & I, III & $33 \%$ & Kurang \\
\hline 18 & P.8 & 4 & III & $33 \%$ & Kurang \\
\hline 19 & P.9 & 4 & I, II, III & $33 \%$ & Kurang \\
\hline 20 & P.10 & 3 & III & $25 \%$ & Kurang \\
\hline 21 & D.1 & 6 & III & $50 \%$ & Kurang \\
\hline 22 & D.2 & 6 & I, II, III & $50 \%$ & Kurang \\
\hline 23 & D.3 & 4 & III & $33 \%$ & Kurang \\
\hline 24 & D.4 & 5 & III & $42 \%$ & Kurang \\
\hline 25 & D.5 & 5 & I, III & $42 \%$ & Kurang \\
\hline 26 & D.6 & 5 & II, III & $42 \%$ & Kurang \\
\hline 27 & D.7 & 5 & III & $42 \%$ & Kurang \\
\hline 28 & D.8 & 5 & III & $42 \%$ & Kurang \\
\hline 29 & D.9 & 4 & III & $33 \%$ & Kurang \\
\hline \multirow[t]{2}{*}{30} & D.10 & 3 & III & $25 \%$ & Kurang \\
\hline & & Rata-rata & & $41 \%$ & \\
\hline
\end{tabular}

Berdasarkan dari uraian tabel diatas dapat disimpulkan subjek penelitian, dalam proses penyampaian pembelajaran tidak melakukan berdasarkan model Van Hiele. Berdasarkan hasil prosentase dari semua subjek dapat disimpulkan rata-rata prosentase hanya mencapai $41 \%$ dengan criteria kurang baik. Sementara untuk mencapai proses penyampaian berdasarkan model Van Hiele harus mencapai minimal 80\% untuk criteria baik. Dengan demikian belum ada guru yang mengajar sesuai dengan model Van Hiele di Kabupaten Asahan.

Tahap Penelitian

Beberapa temuan dalam proses pengumpulan data dan analisis data yaitu banyak sabyek yang menjelaskan kepada siswa hanya sebatas pengetahuan yang terdapat dalam buku paket 
sekolah. Seluruh guru melakukan fase penjelasan hanya menjelaskan definisi, sifat dan rumusrumus bangun datar berdasarkan petunjuk-petunjuk dari alat peraga seadanya. Guru penelitian melakukan interaksi tanya jawab kepada siswa, hanya sebatas pengetahuan awal yang diketahui siswa pada pokok bahasan yang akan dipelajari. Guru tidak melakukan pengecekan kembali tentang pemahaman siswa dari materi pelajaran. berikut:

Guru menggambarkan bangun datar persegi hanya dengan posisi seperti gambar sebagai

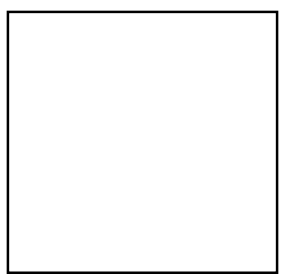

sementara masih ada lagi posis lain dari gambar bangun datar persegi seperti gambar berikut:
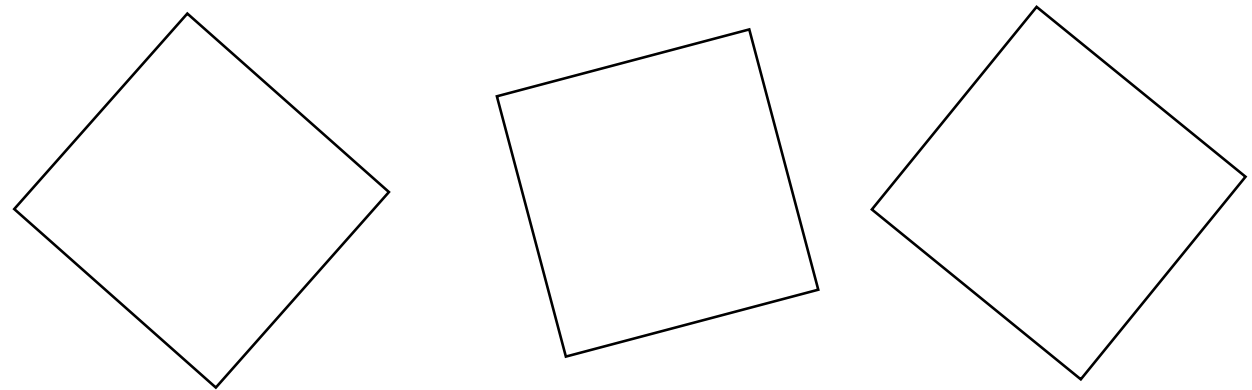

Guru mengambarkan bangun datar persegi panjang hanya dengan posisi seperti gambar sebagai berikut:

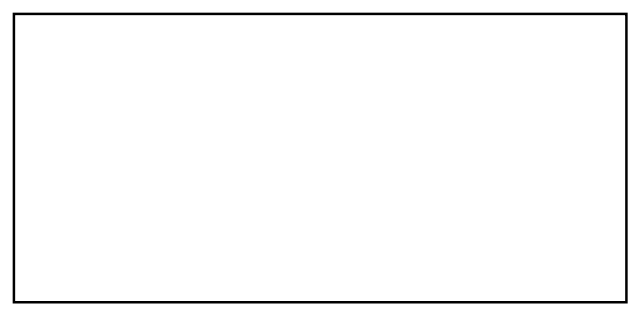

sementara masih ada lagi posis lain dari gambar bangun datar persegi panjang seperti gambar berikut:

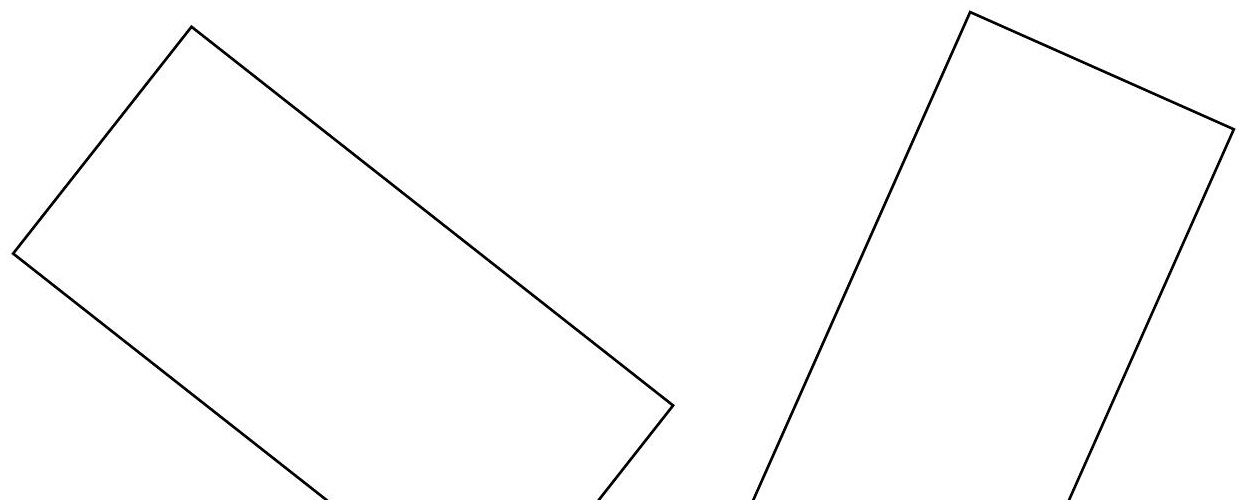


Guru mengambarkan bangun datar segitiga hanya dengan posisi seperti gambar sebagai berikut:
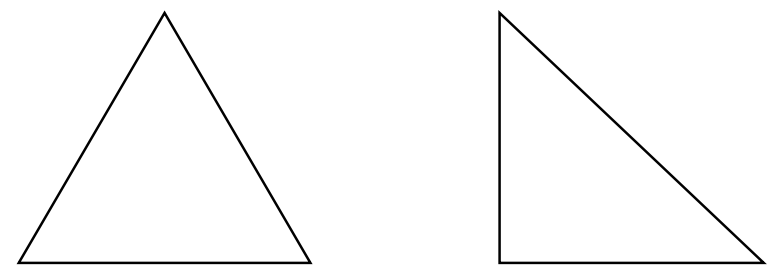

sementara masih ada lagi posisi lain dari gambar bangun durengrenga seperti gambar berikut:
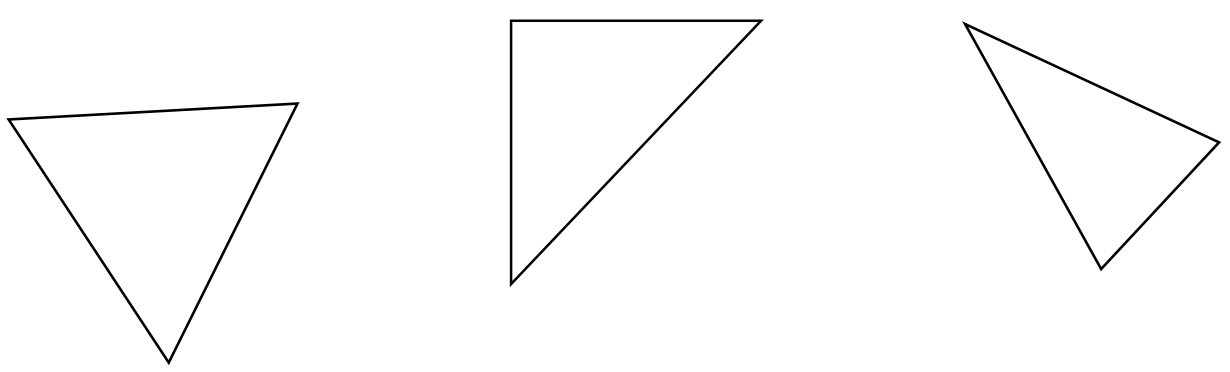

Berdasarkan hasil pembahasan dapat dilihat guru menyampaikan proses pembelajaran, mengantarkan siswa pada level 0 (tingkat Visualisasi) dan belum dikatakan telah melaksanakan teori Van Hiele. Tingkat yang dilalui hanya sebatas pengenalan dasar dari penjelasan yang diutarakan oleh guru. Siswa hanya mengenal bentuk, memahami definisi, dan sifat bangun dari petunjuk dan penjelasan guru. Siswa hanya mengenali komponen-komponen dari masingmasing bangun. Sisiwa hanya mengenal nama bangun dan belum mengamati ciri-ciri bangun secara keseluruan berdasarkan penjelasan guru.

Proses penyampaian pembelajaran pada siswa kelas V (lima) harus sudah mencapai pada level 1 (Tingkat Analisis), karena siswa harus sudah mengenal bangun-bangun geometri berdasarkan ciri-ciri dari masing-masing bangun. Dengan kata lain, pada tingkat ini siswa sudah terbiasa menganalisis bagian-bagian yang ada pada suatu bangun dan mengamati sifat-sifat yang dimiliki oleh unsur-unsur tersebut berdasarkan penjelasan dari guru.

Hasil prestasi anak yang tinggi apabila, guru harus benar-benar membimbing anak untuk melakukan penyelidikan dan menjelaskan materi ajar kepada siswa melibatkan benda-benda dalam kehidupan sehari-hari. Hasil dari analisis data yang didapat semua guru hanya 
memberikan tahap-tahap pengenalan bentuk, sifat, definisi dan hanya mengaikat objek-objek dasar dari bentuk bangun datar.

\section{Simpulan}

Adapun kesimpulan penelitian adalah sebagai berikut:

1. Tahap penyampaian guru dalam tahap awal pembelajaran hanya sebagai pengetahuan yang diketahuai guru tentang materi ajar.

2. Tahap guru menjelaskan kepada siswa menonton dengan metode ceramah/espositori.

3. Tahap guru menemutunjukan dan mendefinisikan bangun-bangun datar berdasarkan petunjuk-petunjuk dari alat peraga berdasarkan buku panduan.

4. Tahap guru untuk membantu siswa untuk menemukan ide-ide mengenai struktur yang diobservasi hanya beberapa guru yang melaksanakan.

5. Berdasarkan hasil analisis data yang diperoleh guru yang mengajar di Kabupaten Asahan tidak melakukan pembelajaran geometri berdasarkan model Van Hiele, sehingga hasil prestasi siswa untuk mengerti geometri pada umumnya masih memiliki nilai rendah.

\section{Daftar Rujukan}

Amirin. T.M.,2003.Pokok-pokok Teori Sistem. PT Raja Grafindo, Jakarta.

Bakti, Darma.2009. Mencermati Sistem Pembelajaran di Tengah Dinamika Globalisasi.

Budiato, M.T., 2000. Pembelajaran Geometrid an Berfikir Geometri. Dalap Prosiding Seminar Nasional Matematika "Peran Matematika Memasuki Millenium III". Surabaya. Jurusan Matematika FMIPA ITS Surabaya.

http://abdussakir.wordpress.com/2009/pembelajaranp-geometri dan teori Van Hiele

http://ahmadrizal.wordpress.com/2008/Pembelajaran_Geometri

http:// kris-21.blogspot.com/2007/12.

http:/ / math.youngzones.org./van-hiele-html 2009.

http://warnadunia.com/teori-pembelajaran-konstruktivisme.

Kunandar, Guru Profesional. Implementasi KTSP dan Sukses dalam Sertifikasi Guru., Jakarta. Rajawali Press.

Kho, ronaldo.1998. tahap Berpikir dan Belajar Geometri Siswa-siswa kelas II SMP Negeri 1 Adepura di Jayapura Berpandu pada Model Van Hiele.

Marno dan M.Idris. 2008. Strategi dan metode pengajaran. Jogjakarta., Ar-Ruzz Media.

Nandika, D, 2007. Pendidikan di tengah Gelombang Perubahan. LP3ES, Jakarta 
Heruman. 2007. Model Pembelajaran Matematika Sekolah Dasar.

Muliawati, Eni. 2000. Pengambangan Perangkat Pembelajaran Geometri dalam Ranhka Pelaksanaan Model Pembelajaran Kooperatif Tipe STAD di SLTP. Tesis. Universitas Negeri Surabaya. Surabaya.

Tenwey G, R. 2004, Belajar dan Pembelajaran. 